\title{
PENTINGNYA PENGETAHUAN PERAWAT DALAM PROSES \\ PERENCANAAN DIAGNOSA KEPERAWATAN
}

\author{
Nuraini Sihite
}

\section{Email: nurainisihite4@gmail.com}

\section{Latar belakang}

Penegakan diagnosis merupakan aspek penting dalam praktik keperawatan. Sepanjang waktu, format dan kualitas penegakan diagnosis telah berkembang, tetapi fokusnya terus berdampak terhadap perawatan klien. Tahap diagnosa keperawatan memungkinkan perawat untuk menganalisis dan mensintesis data yang telah dikelompokkan yang dicantumkan dibawah pola kesehatan dan definisi diagnosa disfungsional. diagnosa keperawatan dirumuskan berdasarkan pada respon klien terhadap perubahan-perubahan pada status kesehatan, masalah-masalah yang diidentifikasi dan kemampuan perawat untuk membantu menemukan penyelesaian masalah.

Diagnosa keperawatan adalah penilaian klinik tentang respon individu keluarga atau komunitas terhadap masalah kesehatan atau proses kehidupan yang aktual atau potensial. Diagnosa keperawatan memberikan dasar untuk pemilihan intervensi keperawatan untuk mencapai hasil yang merupakan tanggung jawab perawat.

Pernyataan diagnosa keperawatan menggambarkan status kesehatan klien dan faktorfaktor yang berkontribusi pada status tersebut titik pernyataan diagnosa keperawatan ditulis oleh perawat untuk masalah-masalah yang diidentifikasi.

Diagnosa keperawatan merupakan pernyataan yang menggambarkan perubahan status kesehatan klien. perubahan-perubahan menyebabkan masalah dan perubahan-perubahan yang tidak menguntungkan pada kemampuan klien untuk berfungsi. Diagnosa keperawatan adalah frase atau pernyataan yang ringkas. diagnosa keperawatan menunjukkan kelompok batasan karakteristik yang gagal memenuhi nilai norma yang diharapkan.

Diagnosa keperawatan memberikan dasar untuk membuat kriteria hasil asuhan keperawatan dan menentukan intervensi intervensi yang diperlukan untuk mencapai kriteria hasil. Jika perawat menemui kesulitan memenuhi diagnosa keperawatan, mungkin terdapat 
kesenjangan informasi titik perawat perlu melakukan pengkajian ulang untuk mengumpulkan data lebih lanjut.

Penegakan diagnosis dalam keperawatan memegang peranan penting terhadap segala macam tuntutan masyarakat yang semakin kritis dan mempengaruhi kesadaran masyarakat akan hak-haknya dari suatu unit kesehatan. Pendokumentasian yang tidak dilakukan dengan lengkap dapat menurunkan mutu pelayanan keperawatan karena tidak dapat mengidentifikasi sejauh mana tingkat keberhasilan asuhan keperawatan yang telah diberikan dalam aspek legal perawat tidak mempunyai bukti tertulis jika klien menuntut ketidakpuasan akan pelayanan keperawatan.

\section{Metode}

Metode yang digunakan pada kajian ini adalah metode kualitatif yang memberikan penjelasan dengan menggunakan analisis pada referensi yang digunakan. Untuk mengumpulkan data-data dari beberapa jurnal dan e-book dari situs internet yang berhubungan dengan topik pembahasan. Karena keterbatasan waktu, cakupan luas dari topik, dan untuk lebih spesifik, maka dilakukan batasan waktu pada tahun publikasinya dengan waktu minimalnya delapan tahun terakhir yaitu dari tahun 2012 dengan mengambil referensi yang terkait dengan topik yang digunakan.

\section{Hasil}

Tahap pertama yang dilakukan dalam proses penulisan dilakukan dengan mengumpulkan data dengan studi dokumentasi asuhan keperawatan yang dijadikan sebagai data dasar. Perumusan diagnosa keperawatan membutuhkan proses berpikir kritis, keterampilan penalaran dan pengalaman sebelumnya.

Seorang perawat memiliki tugas penting yakni memberikan asuhan keperawatan kepada klien/pasien baik individu, kelompok, keluarga atau masyarakat. Dalam pemberian asuhan keperawatan perawat diwajibkan mengikuti proses keperawatan yang terdiri dari pengkajian, diagnosis, perencanaan, pelaksanaan, dan evaluasi. Diagnosis keperawatan merupakan komponen yang sangat penting dalam proses tersebut.

Diagnosis keperawatan merupakan penilaian klinis mengenai respons manusia terhadap kondisi kesehatan/proses kehidupan. Diagnosis keperawatan memberikan dasar untuk pemilihan intervensi keperawatan untuk mencapai hasil yang harus 
dipertanggungjawabkan oleh perawat. Diagnosis keperawatan dikembangkan berdasarkan data yang diperoleh selama asesmen keperawatan dan memungkinkan perawat mengembangkan rencana asuhan.

Diagnosa keperawatan ini merupakan tahap untuk menentukan penilaian klinis terhadap masalah aktual dan masalah kesehatan pada klien yang dapat berpengaruh kepada potensial kehidupan yang akan dijalani oleh klien. Diagnosa keperawatan mencerminkan tingkat kesehatan atau respon klien terhadap terhadap suatu penyakit, proses patologis, status emosional, fenomenas sisokultural dan tahap perkembangan.

Diagnosa keperawatan dikembangkan melalui proses pengkajian dan dikembangkan menggunakan data dasar dari hasil pengkajian ataupun data rekam medik klien sebelumnya. Perbaikan kualitas pada proses pemantauan dan evaluasi hasil dalam pelayanan kesehatan dan bisnis lainnya untuk mengidentifikasi kesempatan untuk memperbaiki kesalahan dalam pendiagnosaan.

Ketika berfokus pada pendiagnosaan keperawatan maka perawat dapat menelaah dan memastikan apakah diagnosa keperawatan yang telah dibuat sudah tapat dengan masalah yang terjadi pada klien atau tidak. Jika diagnosa tersebut tidak tepat, maka perawat wajib memperbaikinya sebelum intervensi ditetapkan

Diagnosa keperawatan diurutkan dengan prioritas tinggi, sedang dan rendah. perawat, klien, keluarga dan orang terdekat berfokus pada usaha-usaha mengatasi masalah klien dengan prioritas tertinggi lebih dulu. Masalah dengan prioritas tinggi mencerminkan situasi yang mengancam hidup (mis, kebersihan jalan nafas). masalah dengan prioritas sedang berhubungan dengan situasi yang tidak gawat dan situasi yang tidak mengancam hidup Kelayan (mis, higiene individu). masalah dengan prioritas rendah tidak berhubungan secara langsung dengan keadaan sakit atau prognosis yang spesifik (mis, memenuhi kebutuhan sosial klien atau masalah keuangan).

\section{Pembahasan}

Keperawatan merupakan profesi unik yang memiliki fokus utama caring, yaitu bagaimana memberikan dan mengelola asuhan yang dibutuhkan pasien. Hal ini menjadikan perawat memiliki peran baik pemberi asuhan sebagai kemampuan klinis dan juga koordinator sebagai komponen manajerial. Peran perawat sebagai pemberi asuhan merupakan komponen penting yang esensial dalam sistem pemberian pelayanan kesehatan. 
Kemampuan dan keterampilan perawat yang kuat dalam kepemimpinan dan administratif sangat penting bagi pasien dan keselamatannya serta sistem layanan dan aksesnya. Mutu asuhan yang unggul dapat memenuhi kebutuhan masyarakat terhadap kesehatan. Tuntutan tersebut membuat perawat perlu dipersiapkan dengan baik untuk membuat dan memelopori strategi perubahan dan mengelola secara efektif koordinasi dan integrasi dari tim interdisipliner, kebutuhan masyarakat, dan sistem asuhan yang berkelanjutan (Koerniawan. 2020 didukung oleh Rabelo et al., 2016). Itulah sebabnya, integrasi asuhan keperawatan dan manajemen keperawatan menjadi salah satu inti kompetensi yang dibutuhkan perawat untuk menjalankan peran dan fungsinya dalam lingkungan layanan asuhan kesehatan.

Perawat adalah seorang profesional yang mempunyai kemampuan, tanggung jawab dan kewenangan melaksanakan pelayanan asuhan keperawatan pada berbagai jenjang pelayanan keperawatan. Pemenuhan kebutuhan kepuasan pasien selama di rumah sakit diperlukan tenaga kesehatan yang harus mempunyai pengetahuan (knowledge), keterampilan (skill) yang tinggi serta mempunyai sikap profesional (attitude) dan dapat menunjang pembangunan kesehatan. Pelayanan yang diberikan akan berkualitas dan dapat memberikan kepuasan pada pasien sebagai penerima pelayanan maupun perawat sebagai pemberi pelayanan (Agung Cahyono dalam Hamid,2000).

Karakteristik dari perawat terdiri dari kemampuan dan ketrampilan fisik dan mental dari individu sebagai perawat. Karakteristik ini dipengaruhi juga oleh latar belakang keluarga, tingkat sosial, pengalaman, umur,jenis kelamin, dan etnis. Perawat sebagai pekerja memiliki karakteristik individu yang berpengaruh terhadap hasil manajemen. Karakteristik ini dapat memberikan hasil manajemen baik dan tidak baik. Demikian pula dengan tingkat pengetahuan perawat sebagai pekerja, dapat mempengaruhi ketrampilan dalam melaksanakan apa yang sudah direncanakan oleh manajemen. (Agung Cahyono., Didukung oleh Gibson dalam Yaslis Ilyas,1999:37).

Diagnosa keperawatan adalah penilaian klinik tentang respon individu keluarga atau komunitas terhadap masalah kesehatan atau proses kehidupan yang aktual atau potensial. Diagnosa keperawatan memberikan dasar untuk pemilihan intervensi keperawatan untuk mencapai hasil yang merupakan tanggung jawab perawat.

Penegakan diagnosis dalam keperawatan memegang peranan penting terhadap segala macam tuntutan masyarakat yang semakin kritis dan mempengaruhi kesadaran masyarakat 
akan hak-haknya dari suatu unit kesehatan. Pendokumentasian yang tidak dilakukan dengan lengkap dapat menurunkan mutu pelayanan keperawatan karena tidak dapat mengidentifikasi sejauh mana tingkat keberhasilan asuhan keperawatan yang telah diberikan dalam aspek legal perawat tidak mempunyai bukti tertulis jika klien menuntut ketidakpuasan akan pelayanan keperawatan.

Diagnosis keperawatan merupakan penilaian klinis terhadap pengalaman/respon individu, keluarga, atau komunitas pada masalah kesehatan/risiko masalah kesehatan atau pada proses kehidupan. Diagnosis keperawatan merupakan bagian vital dalam menentukan asuhan keperawatan yang sesuai untuk membantu klien mencapai kesehatan yang optimal. Perawatan yang profesional dicerminkan dalam pendokumentasian yang profesional, yang membuktikan tentang apa yang dilakukan oleh perawat dan secara efektif menggambarkan status dan kemajuan klien. Informasi yang menggambarkan masalah klien atau diagnosis keperawatan kemudian mengarah pada pemberian asuhan keperawatan untuk memilih suatu rencana perawatan yang sesuai dengan terapi keperawatan (Potter \& Perry; 2009 dalam cikwanto 2018).

Kriteria dari standar diagnosa keperawatan menurut Depkes RI (1998) yaitu diagnosa keperawatan dihubungkan dengan penyebab kesenjangan dan pemenuhan kebutuhan pasien, diagnosa dibuat sesuai dengan wewenang perawat, komponen terdiri dari masalah, penyebab, gejala (PES) atau masalah dan penyebab (PE).

Penilaian diagnosa dapat dipenuhi melalui berkas format diagnosa yang dibuat berdasarkan NANDA-I. NANDA-I berisi gambaran dari semua masalah keperawatan yang ada (memenuhi item diagnosa keperawatan berdasarkan masalah yang telah dirumuskan). Komponen NANDA-I terdiri dari label (problem), faktor yang berhubungan (etiology), dan batasan karakteristik (symptom). Komponen ini membantu dalam proses perumusan diagnosa yang lengkap (memenuhi item diagnosa keperawatan mencerminkan PE/PES).

Jenis diagnosa dalam NANDA-I terdiri diagnosa aktual, resiko (potensial), dan sejahtera (memenuhi item merumuskan diagnosa keperawatan aktual dan potensial).

Penilaian perencanaan dapat dipenuhi melalui berkas format intervensi yang dibuat berdasarkan NOC dan NIC. Perencanaan terdiri dari 2 bagian, yaitu perencanaan tujuan yang didasarkan pada NOC dan perencanaan tindakan yang didasarkan pada NIC. NOC dan NIC 
bisa digunakan secara efektif jika dihubungkan (linkages) dengan NANDA-I (memenuhi item berdasarkan diagnosa keperawatan), (Efendy., A. M. 2012)

Diagnosis keperawatan merupakan sebuah konsep kritis untuk memandu proses pengkajian dan intervensi (Rabelo et al., 2016). Diagnosis juga menjadi komunikasi dan basis ilmu keperawatan dalam interaksinya dengan disiplin ilmu lain. Diagnosis keperawatan merupakan penilaian perawat berdasarkan respon pasien secara holistik (bio-psiko-sosiospiritual) terhadap penyakit atau gangguan kesehatan yang dialaminya. Diagnosis sama pentingnya serta memiliki muatan aspek legal dan etis yang sama dengan diagnosis medis. Oleh karena itu, diagnosis keperawatan merupakan kunciperawat dalam membuat rencana asuhan yang diberikan pada pasien yang dikelola.

Proses identifikasi gangguan kebutuhan berdasarkan respon yang didapat dari pasien diperoleh dari proses pengkajian keperawatan dan kemudian dianalisis untuk penarikan kesimpulan atau keputusan klinis dalam bentuk diagnosis keperawatan. Diagnosis keperawatan mendeskripsikan respon manusia (pasien) terhadap adanya masalah atau gangguan potensial atau aktual, sementara diagnosis medis merupakan konsep yang mendeskripsikan proses penyakit atau injuri. North America Nursing Diagnosis Association (NANDA) yang kemudian berkembang menjadi NANDA-Internasional (NANDA-I) untuk pengembangan dan penggunaan standarisasi terminologi diagnosis keperawatan untuk meningkatkan status kesehatan secara global. Proses pengembangan terus dilakukan untuk perbaikan diagnosis berdasarkan praktik berbasis bukti untuk menentukan tujuan (outcome) dan intervensi yang akan direncanakan dan diberikan kepada pasien (Herdman \& Kamitsuru, 2018). Semakin pendeknya interval diagnosis NANDA-I pada kedua edisi terakhir menunjukkan bahwa perawat perlu lebih sering memperbaharui profesionalitasnya dalam konteks proses keperawatan mengikuti standarisasi yang ada.

Pada pengkajian perawat menemukan berbagai masalah pada klien. Setelah merumuskan diagnosa keperawatan untuk masalah klien, perawat mulai membuat prioritas urutan diagnosa keperawatan. Urutan diagnosa keperawatan tersebut memungkinkan perawat, klien, dan orang terdekat untuk mengatur masalah-masalah klien sesuai dengan urutan kepentingan dan urgensinya.

Diagnosa keperawatan diurutkan dengan prioritas tinggi, sedang dan rendah. perawat, klien, keluarga dan orang terdekat berfokus pada usaha-usaha mengatasi masalah klien dengan prioritas tertinggi lebih dulu. 
1. masalah dengan prioritas tinggi mencerminkan situasi yang mengancam hidup (mis, kebersihan jalan nafas).

2. masalah dengan prioritas sedang berhubungan dengan situasi yang tidak gawat dan situasi yang tidak mengancam hidup Kelayan (mis, higiene individu).

3. masalah dengan prioritas rendah tidak berhubungan secara langsung dengan keadaan sakit atau prognosis yang spesifik (mis, memenuhi kebutuhan sosial klien atau masalah keuangan).

\section{Penutup}

Komponen format asuhan keperawatan yang dikembangkan adalah bagian diagnosa keperawatan, diagnosa keperawatan memberikan dasar untuk pemilihan intervensi keperawatan untuk mencapai hasil yang merupakan tanggung jawab perawat, diagnosa keperawatan merupakan sebuah konsep kritis untuk memandu proses pengkajian dan intervensi.diagnosa keperawatan diurutkan dengan prioritas tinggi, sedang dan rendah. Perawat, klien, keluarga dan orang terdekat berfokus pada usaha-usaha mengatasi masalah klien dengan prioritas tertinggi terlebih dahulu.

\section{Daftar pustaka}

1. Allen, V. C., 1998. Proses keperawatan dengan pendekatan latihan. Jakarta: EGC, halm. 67

2. Simamora, R. H., Bukit, E., Purba, J. M., \&Siahaan, J. (2017). Penguatankinerjaperawatdalampemberianasuhankeperawatanmelaluipelatihanrondekeperaw atan di rumahsakit royal prima medan. Jurnalpengabdiankepadamasyarakat, 23(2), 300-304.

3. Simamora, R. H. (2019). Socialization of Information Technology Utilization and Knowledge of Information System Effectiveness at Hospital Nurses in Medan, North Sumatra. Editorial Preface From the Desk of Managing Editor..., 10(9).

4. Cikwanto, Nupiyanti. 2018. Pengembangan instrumen penegakan diagnosis keperawatan pada pasien congestive heart failure (CHF) berbasis standar diagnosis keperawatan Indonesia (SDKI). Jurnal Keperawatan 'Aisyiyah volume 5, Nomor 1.

5. Ermayani, M., Aprilia Nuryanti. 2017. Pengembangan format pendokumentasian asuhan keperawatan berbasis standardized nursing language (SNL) NANDA-I, NOC dan NIC di ruang rawat inap. Mahakam Nursing Journal Vol 2, No. 2 
6. Suryono, Christianto Nugroho. 2020. Kompetensi Perawat Mendokumentasikan Diagnosis Keperawatan Berdasarkan Standar Diagnosis KeperawatanIndonesia (SDKI). Jurnal ILKES (Jurnal Ilmu Kesehatan) Vol 11, No 1.

7. Cahyono, Agung. 2015. Hubungan karakteristik dan tingkat pengetahuan perawat terhadap pengelolaan keselamatan pasien di rumah sakit. Jurnal Ilmiah WIDYA Volume 3, Nomor 2.

8. Dewi, P. I., dkk. 2020. Analisis Pengetahuan Perawat dalam Menentukan Diagnosis Asuhan Keperawatan Spiritual Islami di Rumah Sakit Syariah. Jurnal Ilmiah Keperawatan Indonesia Vol 4, No 1.

9. Efendy, A. M., dkk., 2012. Perbedaan tingkat kualitas dokumentasi proses keperawatan sebelum dan sesudah penerapan NANDA-I, NIC dan NOC. Jurnal Keperawatan Soedirman (The Soedirman Journal of Nursing), Volume 7, No.2.

10. Mailani, F., Indri Ramadini. Pendamping dan pelatihan pendokumentasian keperawatan Puskesmas lubuk buaya Padang. Jurnal Adimas saintika Volume 1, Nomor 1.

11. Koerniawan, D., dkk. 2020. Aplikasi standar proses keperawatan: Diagnosis, autcome dan intervensi pada asuhan keperawatan. Jurnal Keperawatan Silampari 3 (2).

12. Atmanto, P. A., dkk. 2020. Efektivitas pedoman pendokumentasian diagnosa dan intervensi keperawatan berbasis Android terhadap peningkatan mutu dokumentasi keperawatan di ruang rawat inap.Jurnal Keperawatan dan Kesehatan Masyarakat Vol 9, No 1. 